\title{
Evaluation of two monitoring approaches to assess effects of waste water disposal on histological alterations in fish
}

\author{
D. Bernet ${ }^{1, *}$, H. Schmidt-Posthaus ${ }^{1}$, T. Wahli ${ }^{1}$ \& P. Burkhardt-Holm ${ }^{2}$ \\ ${ }^{1}$ Centre for Fish and Wildlife Health, Institute of Animal Pathology, University of Berne, Laenggass Strasse 122, \\ P.O. Box, CH-3001 Berne, Switzerland \\ ${ }^{2}$ Swiss Federal Institute for Environmental Science and Technology, Ueberlandstrasse 133, CH-8600 Duebendorf, \\ Switzerland \\ (*Author for correspondence)
}

Received 30 October 2003; in revised form 10 December 2003; accepted 9 January 2004

Key words: gills, histopathology, kidney, liver, sewage treatment work, skin, trout, waste water, water pollution

\begin{abstract}
An active monitoring (caging experiment) and a passive monitoring (sampling of wild fish) were performed to investigate the effects of effluent from a sewage treatment works (STW) on brown trout (Salmo trutta) by histopathological examinations of the skin, gill, liver and kidney. Histopathological lesions were evaluated according to a standardised assessment tool, which allows calculation of indices for every organ. According to the results of both monitorings, trout exposed to river water supplemented with treated waste water from the STW Lyss showed higher histopathological indices than trout caught upstream of the discharge point of the STW or kept in river water only. These results indicate a negative effect of treated waste water from the STW on the histopathological status of the examined organs of brown trout. Both monitoring approaches revealed the liver to be the most affected organ compared with reference fish. However, data from the two monitoring approaches were not completely consistent: histologically the gills were the most sensitive organ to the effects of treated waste water in the active monitoring, but were not affected in the passive monitoring. The data provide relevant information about both the comparability and the pros and cons of the two monitoring approaches to assess effects of pollution on histopathological alterations in fish.
\end{abstract}

\section{Introduction}

In many parts of Switzerland fish populations, especially of brown trout, are decreasing (Pedroli et al., 1991; Frick et al., 1998; Friedl, 1999; Burkhardt-Holm et al., 2002). The river "Alte Aare', a medium-sized river in the Swiss midlands, is among the affected water courses. In this river, the fish population was shown to be in decline from the 1960s to the 1980s (Rüfenacht \& Spörri, 1988). In the 1990s, annual censuses revealed a reduction of the fish stock by $85 \%$ over 5 years (Fisheries Authorities of Berne, unpublished data). The river Alte Aare serves as a recipient for treated waste water effluent from the sewage treatment works (STW) Lyss (population equivalent of the period 1995-1997: 59 000-65 000). According to the saprobial index, the water of the river downstream of the discharge point is critically polluted (Aquaplus, 1993). According to unpublished data of the Water and Soil Protection Laboratory in Berne, between 1995 and 1997 BOD $_{5}$ (biological oxygen demand), COD (chemical oxygen demand), and the amount of total insoluble substances in the effluent often exceeded the water quality targets of the water pollution control decree (GSchV, 1998; see also Table 2). The nitrification (1-17\%) and denitrification (17-20\%) of the 
STW were insufficient to attain the water quality targets for ammonia in the river (GSchV, 1998; see also Table 2). Concentrations of polycyclic hydrocarbons (acenaphten, acenaphtylen, anthracen, fluoranthen, fluoren, naphthalin, penanthren, pyren) and synthetic pyrethroids (permethrine) were measured in the effluent within the $\mathrm{ng} \mathrm{l}^{-1}$ range. In a few cases, aromatic hydrocarbons (toluol), phenols (nonylphenoles), halogenated alkanes (dichlormethane, trichlormetane) and halogenated alkenes (tetrachlorethene) were detected within the $\mu \mathrm{g}^{-1}$ range. Considering the number of harmful substances and their concentration, the pollution of the river due to effluent from the STW Lyss is assumed to have a detrimental impact on the resident fish population.

Water pollution has already been suggested in the 1970s to be detrimental to fish health in general (Snieszko, 1974; Sindermann, 1979). However, a clear link between pollution and diseases in wild fish (e.g. skeletal deformities caused by effluent from paper and pulp mills (Lindesjöö \& Thulin, 1990)) is difficult to establish in the field. Histopathology has been used as a biomarker to reveal the effects of pollution in laboratory experiments (e.g. Wester \& Canton, 1991; Schwaiger et al., 1992) as well as field investigations (e.g. Schwaiger et al., 1997; Teh et al., 1997). Histopathology is a suitable indicator to detect and localise toxic effects of substances (McCarthy \& Shugart, 1990; Huggett et al., 1992), but the effects are usually not specific for a particular substance or class of substances. However, only a few studies have been carried out to investigate histopathological effects of STW effluent in freshwater fish (e.g. Mitz \& Giesy, 1985; Carline et al., 1987; Bucher \& Hofer, 1993; Burkhardt-Holm et al., 1997; Schmidt et al., 1999). Theoretically, alterations in organs can directly or indirectly influence fish populations since they (1) can parallel negative effects on the performance of fish (Burrows, 1964), (2) can enhance the susceptibility to secondary diseases (Couillard et al., 1988) or (3) potentially cause fish mortality (Welch \& Lindell, 1980).

The aim of this study was to investigate the effects of treated waste water from the STW Lyss on the skin, gill, liver and kidney. These organs have been proven to be indicative of pollution (e.g. Meyers \& Hendricks, 1985; Hinton \& Laurén, 1990). However, given the difficulties in evaluating the effects of water pollution on fish health as well as the pros and cons of different approaches, we used two different approaches to get several lines of evidence. In the first approach, trout were caged in the river (active monitoring). The advantages of this method are standardised conditions as far as possible, adjustable exposure time, known origin and health status of the fish and the possibility of surveying fish during the experiment. In the second approach, wild fish in the river were investigated (passive monitoring). The advantages of this method are that effects can be studied in fish showing adapted behaviours (e.g. avoidance, feeding) and physiology whilst living under natural conditions in a polluted system. Besides evidence for effects of treated effluents on fish histology, we expect data of both monitorings to provide valuable information about the comparability of results derived from these two commonly used approaches.

\section{Materials and methods}

The river Alte Aare has a residual water-flow of $3.5-4 \mathrm{~m}^{3} \mathrm{~s}^{-1}$, regulated by a hydroelectric power station about $8 \mathrm{~km}$ upstream of the STW. Between the power plant and the STW only a few small tributaries flow into the river Alte Aare. The dilution ratio of treated waste water $\left(0.2 \mathrm{~m}^{3} \mathrm{~s}^{-1}\right)$ at the point of discharge is approximately 1:20.

The experiments were carried out between May 1995 and April 1997. In the active monitoring, two cages $(1.2 \times 0.8 \times 0.5 \mathrm{~m})$ built of perforated aluminium were deployed in the river. Into one cage, placed $20 \mathrm{~m}$ above the discharge point of the STW, treated waste water was continuously pumped (hereafter called WW (waste water)group). The resulting dilution of waste water in the cage corresponded with that of the waste water dilution at the point of discharge into the river. Being situated downstream of the rainwater overflow of the STW, this cage additionally received untreated waste water in the case of heavy rainfall (Table 1). The second cage (hereafter called RW (river water)-group) was placed upstream of the discharge point of the STW and the WW-cage. Therefore, fish were exposed to river water only. During the first stocking, this cage was located below the rainwater overflow. For the subsequent 
Table 1. Active monitoring: stocking of the cages (number of fish exposed in each cage with average length and weight of fish at the beginning of the stockings) and number of sampled fish from each cage and at each sampling

\begin{tabular}{|c|c|c|c|c|}
\hline & 1. Stocking & 2. Stocking & 3. Stocking & 4. Stocking \\
\hline & May-July 1995 & $\begin{array}{l}\text { October } 1995- \\
\text { April } 1996\end{array}$ & May-August 1996 & $\begin{array}{l}\text { October 1996- } \\
\text { April } 1997\end{array}$ \\
\hline Number of fish exposed in each cage & 80 & 40 & 40 & 40 \\
\hline Average length of fish (RW-group/WW-group) & $14 \mathrm{~cm} / 13 \mathrm{~cm}$ & $18 \mathrm{~cm} / 18 \mathrm{~cm}$ & $16 \mathrm{~cm} / 17 \mathrm{~cm}$ & $18 \mathrm{~cm} / 18 \mathrm{~cm}$ \\
\hline Average weight of fish (RW-group/WW-group) & $22 \mathrm{~g} / 20 \mathrm{~g}$ & $66 \mathrm{~g} / 63 \mathrm{~g}$ & $50 \mathrm{~g} / 52 \mathrm{~g}$ & $75 \mathrm{~g} / 72 \mathrm{~g}$ \\
\hline \multicolumn{5}{|l|}{$\begin{array}{l}\text { Number of sampled fish and exposure time } \\
\text { (in weeks) at sampling }\end{array}$} \\
\hline 1. Sampling & $5(8)$ & $5(8)$ & $5(1)$ & $5(2)$ \\
\hline 2. Sampling & $5(9)$ & $5(17)$ & $5(7)$ & $5(9)$ \\
\hline 3. Sampling & a & $5(26)$ & $1 / 5^{\mathrm{b}}(13)$ & $5(18)$ \\
\hline 4. Sampling & a & a & a & $6(26)$ \\
\hline \multicolumn{5}{|l|}{ Rainwater overflow of the STW } \\
\hline Number of days & 16 & 38 & 24 & 58 \\
\hline Volume $\left(\mathrm{m}^{3}\right)$ & 89000 & 118630 & 52570 & 141300 \\
\hline
\end{tabular}

Exposure time of fish at samplings are given in parentheses (weeks). Additionally, number of days and volumes of raw waste water discharging due to the rainwater overflow of the STW are shown. Except for the first stocking, only WW-trout were additionally exposed to untreated waste water from the rainwater overflow.

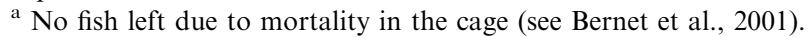

${ }^{\mathrm{b}}$ One fish out of cage RW and five fish out of cage WW.

stockings, this cage was fixed $50 \mathrm{~m}$ upstream of the rainwater overflow. During the experiments, water temperature over the year ranged from 3 to $20{ }^{\circ} \mathrm{C}$ and oxygen concentration from 4 to $14 \mathrm{mg} \mathrm{l}^{-1}$ in each cage. Mean temperature and oxygen differences between the cages were $\leq 0.5^{\circ} \mathrm{C}$ and $\leq 1.0 \mathrm{mg}^{-1}$, respectively. Further physiochemical water data as well as the location of the sites are summarised in Table 2.

One-year-old brown trout obtained from a governmental fish farm were placed into the cages. Four stockings were performed, each of them exposing 40 fish, except the first stocking where 80 trout were exposed. At the beginning of the stockings, average fish weight was $20-75 \mathrm{~g}$ (Table 1). As a reference, brown trout of the same origin and age were kept in commercial tap water at the laboratory in a 2000-1 fibreglass tank (approximately 200 trout per tank). All fish were fed commercial trout pellets (Hokovit, Bützberg, Switzerland) three times a week, with a ration equal to $1-2 \%$ of body weight. In general, every second month, five fish from each cage were randomly sampled. Samplings and exposure time of fish are shown in Table 1. Sampling of the reference fish (five fish per sampling) was performed in June and October 1995, October 1996 and February 1997.

In the passive monitoring, wild brown trout were caught by electrofishing in the river. The sampling sites were located upstream (hereafter called UP-group) and downstream (hereafter called DOWN-group) of the discharge point of the STW. Four samplings took place between August 1995 and January 1997. Between 5 and 14 wild fish were collected per sampling site (Table 3). The sites, their locations and physiochemical conditions of the water at the respective sites are summarised in Table 3.

Sampled fish were euthanised in Tricaine Methanesulfonate (Argent Chemical Laboratories, Redmont, USA), then weighed and measured. Pieces of skin (laterally in front of the dorsal fin), gill, liver and kidney (under the dorsal fin) were fixed in Bouin's solution for $24 \mathrm{~h}$, cut into $5 \mu \mathrm{m}$ thick sections and stained with haematoxylin-eosin (HE) for general histological evaluation and periodic acid-schiff (PAS) for identification of neutral carbohydrates and glycoproteins (e.g. deposits, 


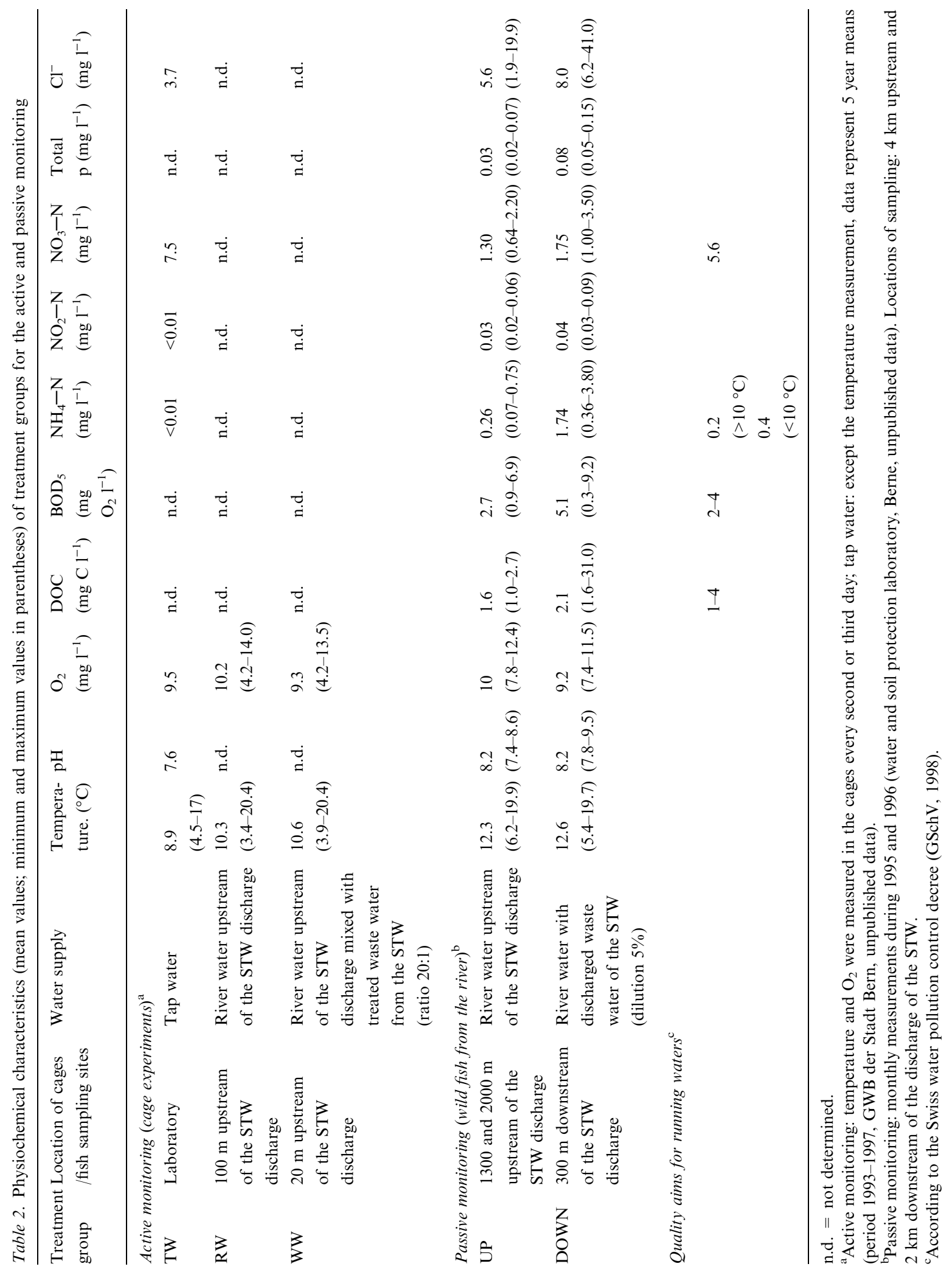


hyalinised glomeruli). Histopathological changes of the four organs were assessed according to a standardised assessment tool (Bernet et al., 1999). Briefly, the lesions are classified into five reaction patterns: circulatory, regressive, progressive, inflammatory and neoplastic. Every alteration has an importance factor ranging from 1 to 3 . This factor characterises the pathological relevance. The degree and extent of an alteration is assessed using a score value ranging from 0 to 6 . For every organ, an organ index is calculated by the sum of the multiplied importance factors and score values of all alterations found within the examined organ. The sum of all four organ indices per fish results in a total index (Tot-I) for the respective fish. The higher the index values, the more severe the organs are affected.

Sampled fish were investigated bacteriologically, virologically and parasitologically (results are published in Bernet et al., 2001). This allowed us to distinguish between pollution-associated and infection-associated organ lesions.

\section{Statistical analysis}

Due to the limited sample size, group differences at each sampling time of the four stockings of the active monitoring were calculated with the nonparametrical Mann-Whitney $U$ test (Fig. 1). For further statistical analyses, the four stockings in the active monitoring were analysed as repeated measures, thus with a larger sample size for the different groups. After testing for normal distribution of the data we were able to use a multifactorial analysis of covariance (MANCOVA) for the histopathological indices of the trout from the active monitoring, to test the influence of water quality and exposure time. Pairwise comparisons between means were performed using least-squaremeans (LSM) adjustments. In the passive monitoring, differences of the histopathological indices between the two sites were tested using a MannWhitney $U$ test. For histopathological alterations, relative risk (prevalence ratio) values were calculated dividing the prevalence of an alteration of WW-fish by the respective prevalence of RW-fish (active monitoring), and DOWN-fish by UP-fish (passive monitoring), respectively. These were tested using $\chi^{2}$-test according to Pearson, Mantel and Haensel (Sachs, 1999). For all statistics, a $p$ value of $\leq 0.05$ was considered as significant, with a Bonferroni correction used in cases of multiple testing with the non-parametrical tests.

\section{Results}

Active monitoring

Generally, Tot-I values were higher in WW-trout than in RW-trout, indicating that histopathological

Table 3. Passive monitoring: location of the sampling sites (UP = wild fish upstream from the inflow of treated effluent from the STW; DOWN = wild fish downstream from the inflow of treated effluent from the STW) and number, length, weight and sex of the sampled fish (juv $=$ juvenile)

\begin{tabular}{|c|c|c|c|c|c|}
\hline Sampling site & $\begin{array}{l}\text { Distance of the site } \\
\text { from the STW }(\mathrm{m})\end{array}$ & $\begin{array}{l}\text { Number of } \\
\text { fish sampled }\end{array}$ & Length $(\mathrm{cm})$ & Weight (g) & Sex \\
\hline \multicolumn{6}{|c|}{ 1. Sampling: 7th August 1995} \\
\hline UP & 1300 & 5 & $16.0-20.5$ & $44-96$ & $5 \times$ juv \\
\hline DOWN & 300 & 6 & $17.0-28.5$ & $50-311$ & $6 \times$ juv \\
\hline \multicolumn{6}{|c|}{ 2. Sampling: 23th January 1996} \\
\hline UP & 1300 & 8 & $13.5-28.5$ & $23-226$ & $4 \times$ juv; $4 \times$ female \\
\hline DOWN & 300 & 7 & $12.5-19.0$ & $19-78$ & $5 \times$ juv; $2 \times$ female \\
\hline \multicolumn{6}{|c|}{ 3. Sampling: 23th July 1996} \\
\hline UP & 1300 & 8 & $13.5-27.0$ & $22-208$ & $5 \times$ juv; $3 \times$ female \\
\hline DOWN & 300 & 3 & $18.5-31.0$ & $77-370$ & $1 \times$ male; $2 \times$ female \\
\hline \multicolumn{6}{|c|}{ 4. Sampling: 14th January 1997} \\
\hline UP & 2000 & 14 & $11.0-25.0$ & $12-145$ & $5 \times$ juv; $9 \times$ female \\
\hline DOWN & 300 & 10 & $13.0-27.5$ & $19-230$ & $4 \times$ juv; $6 \times$ female \\
\hline
\end{tabular}




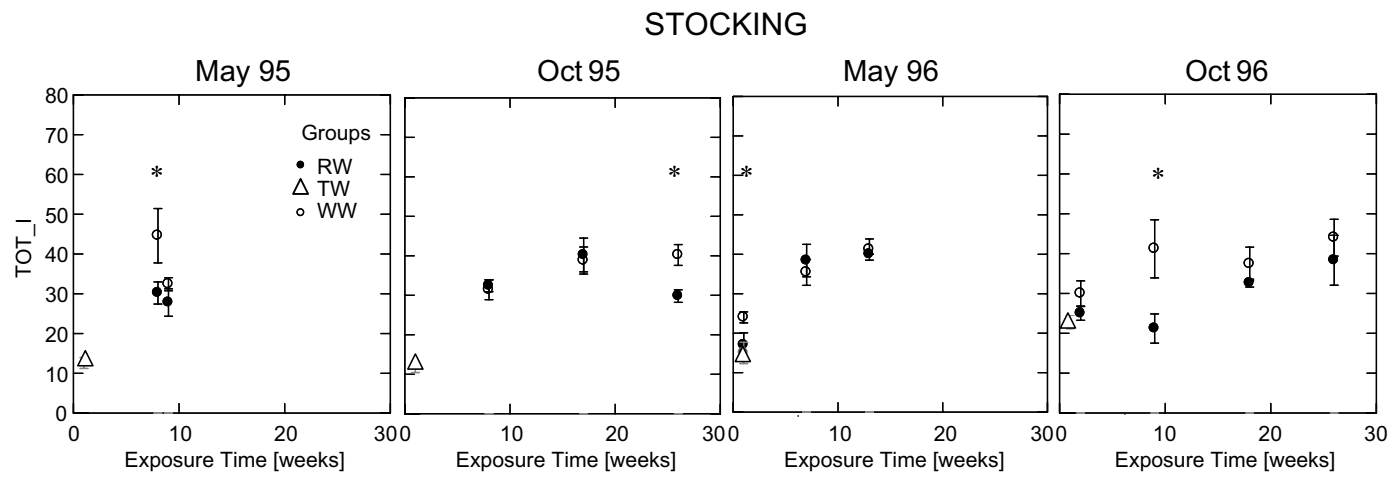

Figure 1. Active monitoring: total index (Tot_I = sum of the four indices of gills, skin, liver and kidney) of trout exposed to river water (RW-group), trout kept in waste water from the STW diluted with river water (WW-group), and trout held in tap water (TW-group). The four figures represent the results of the four stockings launched in May 95, October 1995, May 1996 and October 1996, respectively. The asterisks indicate significant differences between the groups (Mann-Whitney $U$ test, $p<0.05$ ). The variability of the mean values (round symbol) are displayed by standard error bars.

lesions in waste water exposed trout were more pronounced than in trout caged in river water (Fig. 1). However, differences between the Tot-I values of WW-trout and RW-trout were only significant at one sampling in each of the four stockings (Mann-Whitney $U$ test; $p<0.05$; Fig. 1). The exposure time was not crucial for significant differences.

When the four different stockings per group were considered as repeated measures (and thus taken as one group for statistical analyses), both groups (WW- and RW-group) revealed significantly higher Tot-I than the reference group (MANCOVA; LSM; $p=0.0001$; Table 4). On the organ index level, the only significant difference between WW-trout and RW-trout was observed in the gills (MANCOVA; LSM; $p=0.0001$; Table 4). With the exception of the skin index, all organ indices of WW- and RW-trout were significantly higher than the corresponding values of the reference group (MANCOVA; LSM; $p \leq 0.015$ ). The liver indices of the WW-trout (268\%) and of the RW-trout (239\%) showed the most distinctive percentage increase compared with the value of the reference group.

In respect to the duration of exposure, a significant positive correlation was found for the TotI (MANCOVA; $T=5.33 ; p=0.0001$ ), the gill index (MANCOVA; $T=6.03 ; p=0.0001$ ), the liver index (MANCOVA; $T=3.79 ; p=0.0002$ ) and, less pronounced, also for the kidney index (MANCOVA; $T=2.42 ; p=0.017$ ). The skin index decreased slightly with increased exposure time (MANCOVA; $T=-2.41 ; p=0.017$ ). Apart from a slight partial correlation between the liver and the kidney index $(r=0.19 ; p=0.03)$, no interactions between the indices were found.

\section{Skin}

In all groups, a slightly irregular structure of the basal cell layer and leukocyte infiltration was observed. Epithelial cells in 25\% of WW- and RWfish showed irregular shaped nuclei (Fig. 2e) and in $10 \%$ of the fish, the cytoplasm of the epithelial cells was granulated.

\section{Gill}

Epithelial cell lifting, infiltration of the gill epithelium, epithelial hypertrophy and hyperplasia, alterations in the epithelial cytoplasm (Fig. 2b), slight deformations of the primary and secondary lamellae and fusion of adjacent lamellae (Fig. 2c) were more prevalent and more pronounced in WW-trout and RW-trout than in the reference fish. WW-trout also exhibited a significantly higher relative risk (prevalence ratio) of plasma alterations in the epithelial cells, deformation of the primary and secondary lamellae, hyperplasia of the epithelium and fusion of adjacent lamellae than RW-trout (Table 5). Furthermore, these lesions were more pronounced in WW-trout. 
Table 4. Values (means $\pm \mathrm{SD}$ ) of the five histopathological indices of the active monitoring groups (WW-group $=$ fish exposed to treated waste water from the STW diluted with water of the river; RW-group = fish kept in river water; TW-group $=$ reference fish held in tap water) and the passive monitoring groups (UP = wild fish upstream from the inflow of treated effluent from the STW; DOWN = wild fish downstream from the inflow of treated effluent from the STW)

\begin{tabular}{lcccccc}
\hline Indices & Active monitoring & & & \multicolumn{3}{l}{ Passive monitoring } \\
\cline { 2 - 3 } \cline { 6 - 7 } & $\mathrm{TW}(n=20)$ & $\mathrm{RW}(n=57)$ & $\mathrm{WW}(n=61)$ & $\mathrm{UP}(n=26)$ & DOWN $(n=35)$ \\
\hline Total index & $15.6 \pm 5.6$ & $30.3 \pm 9.5^{\mathrm{a}}(94 \%)$ & $36.8 \pm 9.5^{\mathrm{a}, \mathrm{b}}(136 \%)$ & $34.2 \pm 9.9^{\mathrm{c}}(119 \%)$ & $40.0 \pm 9.6^{\mathrm{c}}(156 \%)$ \\
Skin index & $2.0 \pm 0.9$ & $2.9 \pm 2.2(45 \%)$ & $2.8 \pm 1.8(40 \%)$ & $2.4 \pm 2.2(20 \%)$ & $3.3 \pm 1.9(65 \%)$ \\
Gill index & $6.6 \pm 3.0$ & $9.2 \pm 3.2^{\mathrm{a}}(39 \%)$ & $14.2 \pm 4.7^{\mathrm{a}, \mathrm{b}}(115 \%)$ & $9.0 \pm 2.7(36 \%)$ & $9.7 \pm 2.7^{\mathrm{e}}(47 \%)$ \\
Liver index & $3.1 \pm 2.9$ & $10.5 \pm 4.9^{\mathrm{a}}(239 \%)$ & $11.4 \pm 4.7^{\mathrm{a}}(268 \%)$ & & $14.1 \pm 7.5^{\mathrm{d}}(355 \%)$ & $16.3 \pm 7.2^{\mathrm{e}}(426 \%)$ \\
Kidney index & $4.7 \pm 3.4$ & $7.8 \pm 4.6^{\mathrm{a}}(66 \%)$ & $8.7 \pm 4.9^{\mathrm{a}}(85 \%)$ & & $8.9 \pm 3.3(89 \%)$ & $10.6 \pm 3.8^{\mathrm{e}}(125 \%)$ \\
\hline
\end{tabular}

The percentage increase of the values compared with the corresponding index value of the reference group (TW) are shown in parentheses.

Group differences of the active monitoring:

${ }^{a}$ Denotes significant differences compared to the corresponding index value of the reference group (MANCOVA; LSM; $p \leq 0.015$ ).

${ }^{\mathrm{b}}$ Denotes significant differences of the WW-group compared to the corresponding index value of the RW-group (MANCOVA; LSM; $p=0.0001)$.

Group differences of the passive monitoring:

${ }^{c}$ Denotes significant differences between the two groups of the passive monitoring (Mann-Whitney $U$ test; Bonferroni-corrected; $p=0.024)$.

Comparison of data from the active and the passive monitoring ( $R W$ vs. UP and $W W$ vs. DOWN):

${ }^{\mathrm{d}}$ Denotes significant differences between RW-group and UP-group (Mann-Whitney $U$ test; Bonferroni-corrected; $p=0.011$ ).

${ }^{\mathrm{e}}$ Denotes significant differences between WW-group and DOWN-group (Mann-Whitney $U$ test; Bonferroni-corrected; $p=0.001$ for the gill index, $p=0.002$ for the liver index, $p=0.025$ for the kidney index).

Liver

Some fish of the reference group showed slight structural disorder of the hepatocytes, granular cytoplasm and mild inflammatory reactions. In WW- and RW-trout, these alterations were more severe and more frequent. Additionally, necrosis of hepatocytes (Fig. 2g), pericholangiar proliferation of fibroblasts with lymphocytic infiltration (Fig. 2h) and an increase in number and size of Kupffer cells of the reticulo-endothelial system (RES) were noted. Twenty-five percent of WWand RW-trout revealed nuclei alterations (i.e. pyknosis, karyomegaly) of the hepatocytes. Sixty percent showed small foci of infiltrated lymphocytes and macrophages. In 3\% of WW-trout, PKX cells accompanied by a mild to moderate fibrosis and a lymphohistiocytic infiltration were seen. Compared with RW-trout, WW-trout exhibited increased (partly significant) relative risk (prevalence ratio) of structural disorder, necrosis of hepatocytes, pericholangiar proliferation of fibroblasts and an increase in number and size of $\mathrm{Ku}-$ pffer cells of the RES (Table 5).
Kidney

In fish of all groups, kidney alterations consisted mainly of plasma alterations in tubular cells (e.g. hyaline droplet degeneration), glomeruli and interstitial tissue, deposits in tubules and in the interstitial tissue (Fig. 2j), as well as thickening of Bowman's capsular endothelium and fibroblast proliferation around tubules. However, in reference fish, these alterations were less prevalent and less pronounced than in WW- and RW-trout. Among these alterations, only hyalinous deposits in the tubules and in the interstitial tissue occurred to a higher extent in WW-trout than in RW-trout (Table 5). In $12 \%$ of the WW-trout and $9 \%$ of RW-trout, PKX cells were detected, associated with a mild to severe proliferation of the interstitial tissue.

\section{Passive monitoring}

In three of four samplings, fish from downstream of the point of STW discharge showed higher histological lesions (Fig. 3). At the sampling in 

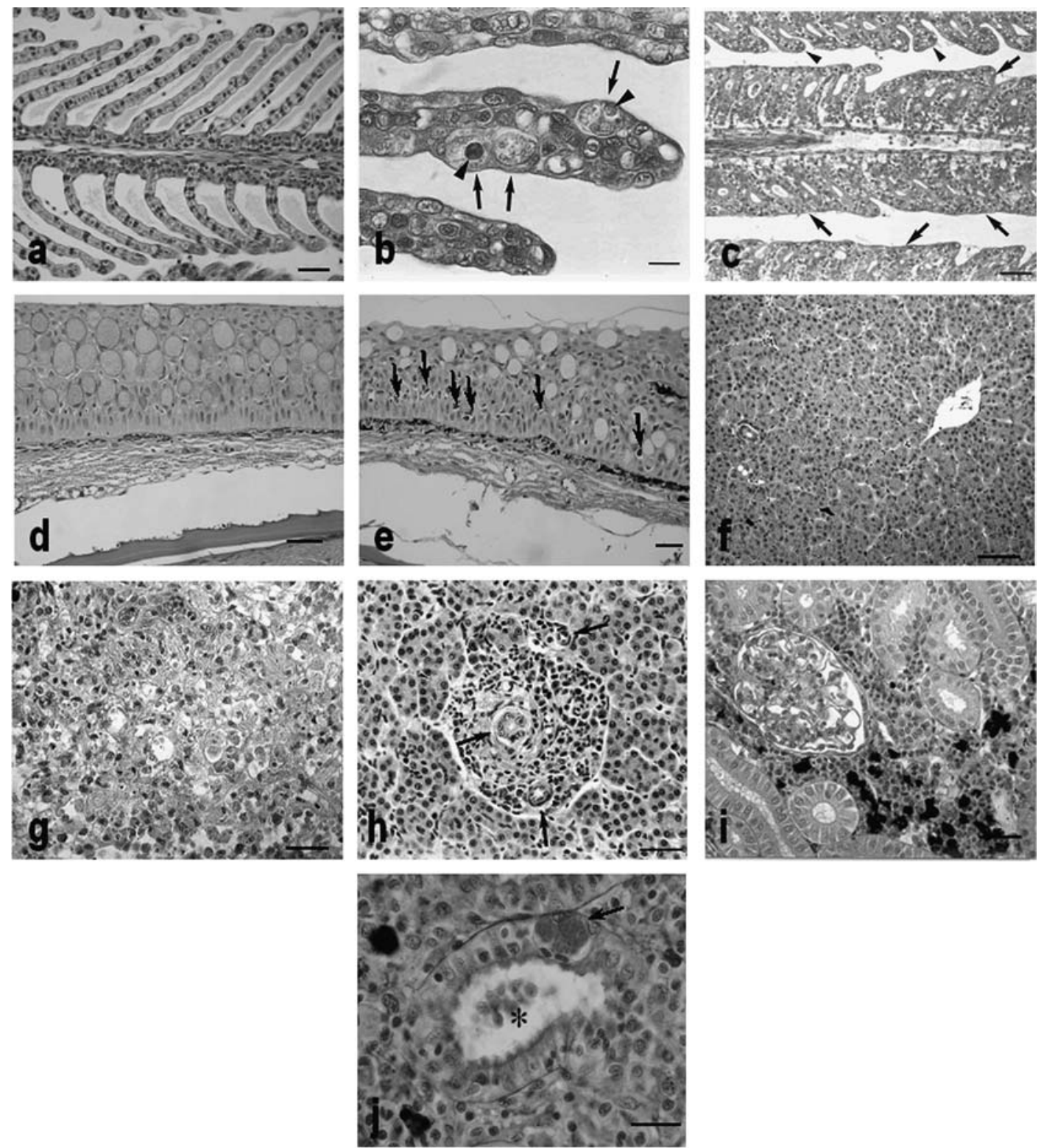

Figure 2. Representative micrographs of histological sections of gills (a-c), skin (d-e), livers (f-h) and kidney (i-j) from brown trout. (a) Cross section of unaltered gills from a trout kept in tap water. Bar $=30 \mu \mathrm{m}$, HE. (b) Gill section of a WW-trout after 26 weeks of exposure. Note the foamy cytoplasm (arrows) partly with eosinophilic inclusions (arrowhead) of the moderately to severely hypertrophic epithelial cells. Bar $=10 \mu \mathrm{m}$, HE. (c) Gill section of a WW-trout after 26 weeks of exposure. Note the hyperplasia of the epithelial cells (arrowheads) with the severe fusion of the lamellae (arrows). Bar $=50 \mu \mathrm{m}$. HE. (d) Cross section of normal skin from a trout hold in tap water. Bar $=35 \mu \mathrm{m}$, HE. (e) Skin section of WW-trout after 2 weeks of exposure. Note the irregular shaped nuclei above the basal epithelial layer. Bar $=30 \mu \mathrm{m}$, HE. (f) Cross section of a normal liver from a WW-trout after 2 weeks of exposure. Bar $=100 \mu \mathrm{m}$, HE (g) Liver section of a wild trout caught downstream of the STW. Note the distinct necrotic tissue. The nuclei of the necrotic cells undergo pyknosis and karyorrhexis. Single cells separate, the cytoplasm is basophilic, and the cells dissolve. Bar $=50 \mu \mathrm{m}$, HE. (h) Liver section of a wild trout caught upstream of the STW. Note the moderate pericholangiar proliferation of fibroblasts with a moderate lymphohistiocytic infiltration. The bile ducts are shown with arrows. Bar $=30 \mu \mathrm{m}$, HE. (i) Cross section of normal kidney tissue from a trout kept in tap water. Bar $=50 \mu \mathrm{m}$, HE. (j) Kidney section of a wild trout caught downstream of the STW. Note the round hyalinous deposits in tubular cells (arrow) displacing the nuclei of the tubular cells to the margin. The asterisks marks sporogonic stages of a myxosporidian parasite (most probably Sphaerospora sp.) in the renal tubule. Bar $=20 \mu \mathrm{m}$, PAS. 
Table 5. Relative risk values (prevalence ratios) for some histological alterations in the organs skin, gill, liver and kidney to occur in the two river groups of the active (WW- vs. RW-group) and the passive monitoring (UP- vs. DOWN-group)

\begin{tabular}{lll}
\hline Alterations & WW/RW & DOWN/UP \\
\hline Skin & & $5.8(<\mathbf{0 . 0 0 1})$ \\
Nuclear alterations in epithelial cells (i.e. kidney shaped) & $1.0(-)$ & \\
Gill & $1.6(<\mathbf{0 . 0 0 1})$ & $3.7(<\mathbf{0 . 0 0 1})$ \\
Plasma alterations of the epithelial cells (i.e. desquamating, granulation) & $2.0(<\mathbf{0 . 0 1})$ & 0.8 (n.s.) \\
Curvatures of primary and secondary lamellae & $1.2(<\mathbf{0 . 0 0 1})$ & 1.1 (n.s.) \\
Hyperplasia of the epithelium & $9.7(<\mathbf{0 . 0 0 1})$ & - \\
Lamellar fusion & & 1.1 (n.s.) \\
Liver & 1.2 (n.s.) & 4.0 (n.s.) \\
Structural changes of hepatocytes & 3.7 (n.s.) & 1.2 (n.s.) \\
Necrosis of hepatocytes & 1.3 (n.s.) & $1.0(-)$ \\
Pericholangiar proliferation of fibroblasts associated with infiltration of lymphohistiocytes & 1.3 (n.s.) & \\
Activation of the reticulo-endothelial-system & & $0.7(<0.05)$ \\
Kidney & $1.3(<0.05)$ & 0.8 (n.s.) \\
Hyalinous deposits in tubules & 1.3 (n.s.) \\
Hyalinous deposits in the interstitial tissue &
\end{tabular}

Significance levels (Bonferroni-corrected per organ) are given in parentheses.

Significant values are indicated in bold type; near-significant values are indicated by italicized $p$-values.

n.s. $=$ not significant.

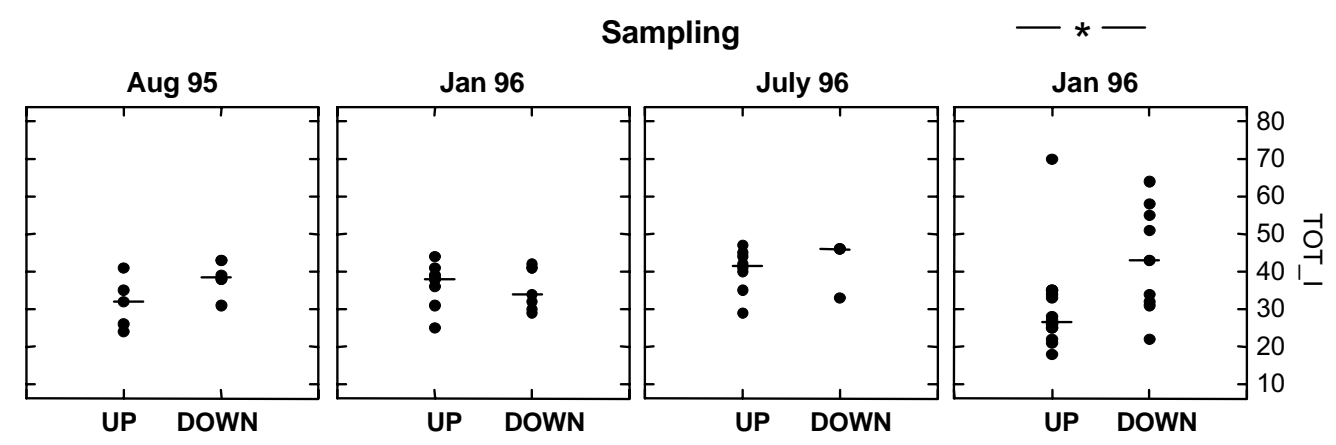

Figure 3. Passive monitoring: total index (Tot_ $\mathrm{I}=$ sum of the four indices of gills, skin, liver and kidney) of trout from downstream (DOWN-group) and upstream of the STW discharge (UP-group) at the four samplings. The thin horizontal lines indicate median values of the respective group. The asteriks indicate significant differences between the groups (Mann-Whitney $U$ test; $p=0.02$ ).

January 1997, these differences were significant (Mann-Whitney $U$ test; $U=31.0 ; p=0.02$ ). Taking together the data of the four samplings, differences of Tot-I between trout from DOWNgroup and fish caught upstream the STW discharge become significant (Mann-Whitney $U$ test; $U=609.5 ; p=0.024$; Fig. 4). Indices of all four organs were higher in DOWN-trout, however, the values did not differ significantly (Table 4). There was no significant seasonal difference between TotI values of winter and summer samplings (MannWhitney $U$ test, DOWN-group: $U=83.5$; $p>0.05$; UP-group: $U=199.5 ; p>0.05)$, and no correlation between Tot-I and length and weight of the fish, respectively (Spearman-Test; $\left.r_{\mathrm{s}}<0.305 ; p>0.05\right)$.

The lesions observed in the organs of wild fish corresponded with those found in fish of the active 


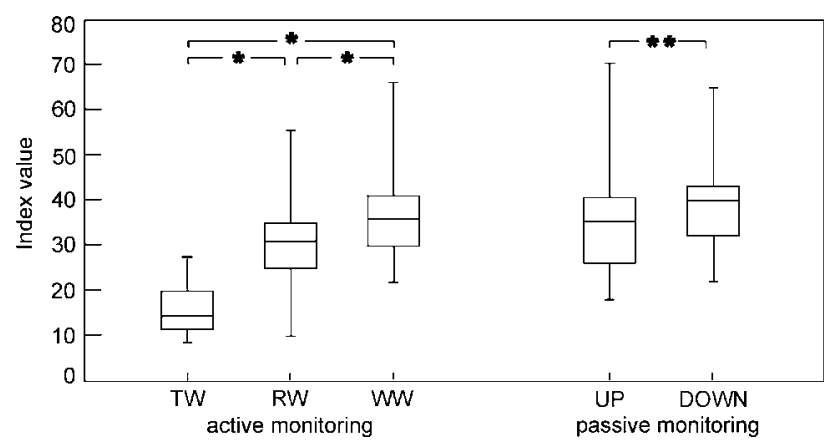

Figure 4. Total indices of the active monitoring groups (TW-group $=$ reference fish held in tap water $(n=20)$; RW-group $=$ fish kept in river water $(n=57)$; WW-group $=$ fish exposed to treated waste water from the STW diluted with water from the river $(n=61))$ and the passive monitoring groups (UP-group $=$ wild fish from upstream $(n=35)$; DOWN-group $=$ wild fish downstream from the inflow of effluent from the STW $(n=26))$. * Denotes significant differences within the active monitoring (MANCOVA; LSM; $p \leq 0.0001)$; ** Denotes differences within the passive monitoring (Mann-Whitney $U$ test; $p=0.024$ ).

monitoring. However, in the skin, fish from downstream of the STW had a significantly higher relative risk (prevalence ration) of nuclear alterations in epithelial cells than fish from upstream (Table 5). In the gills, no lamellar fusions were present. As in the active monitoring, fish from downstream of the STW had a significantly higher relative risk of plasma alterations of gill epithelial cells than fish from upstream of the STW (Table 5). In addition to liver lesions seen in the active monitoring, haemorrhages ( $8 \%$ of UP- and DOWN-trout), nuclei alterations in bile duct cells (11\% of UP-trout) and slight cirrhosis (12\% in UPand $9 \%$ in DOWN-trout, respectively) occurred. In the kidney, deposits in the tubules and in the interstitial tissue were more prevalent in UP-trout (Table 5).

\section{Active monitoring vs. passive monitoring}

In both monitorings, sewage water exposed trout (WW-group of the active monitoring and DOWNgroup of the passive monitoring) showed significantly higher Tot-I values than trout exposed to river water (RW-group of the active monitoring and UP-group of the passive monitoring) (Table 4 and Fig. 4). The Tot-I values of trout from the UP-group (passive monitoring; median value: 35 ) corresponded with those from the RW (active monitoring; median value: 31) and did not differ significantly from each other (Mann-Whitney $U$ test; $U=785.5 ; p>0.05$ ). This was also true for trout from the DOWN-group (passive monitoring; median value: 40) compared with trout from WWgroup (passive monitoring; median value: 36 ). Nevertheless, despite of adequate Tot-I values, trout from the two approaches responded differently to the water quality on the level of the organ indices: Compared with STW exposed trout from the active monitoring (WW-trout), trout from the passive monitoring downstream of the STW discharge (DOWN-group) showed significantly less gill alterations, but significantly higher liver and kidney alterations (Table 4). This was also true for $\mathrm{RW}$-trout compared with UP-trout, however, the differences were only significant for the liver alterations.

\section{Discussion}

The results of both monitoring approaches indicate that river water without supplemented waste water from the STW Lyss caused marked histopathological lesions in trout. In fact, there are five additional STWs within $40 \mathrm{~km}$ upstream of the discharge of the STW Lyss, deteriorating the water quality of the river Alte Aare. The effluent from the STW Lyss, however, significantly enhanced the histopathological alterations of exposed fish. This significant negative effect of treated waste water from the STW on fish organs was revealed by both monitoring approaches. However, despite this the Tot-I values of the corresponding groups in both approaches were approximately equivalent, reflecting different responses of the four organs 
within the two monitorings: In the active monitoring, marked gill lesions were observed. The gills turned out to be the most indicative organ to reveal significant differences between waste water and river water exposed trout of the active monitoring. In contrast, the two groups of the passive monitoring showed not significantly different and rather mild gill lesions, but more pronounced liver and kidney indices.

We suggest that these inconsistencies of the histopathological results of the two approaches may partly be due to methodological peculiarities. The advantage of the active monitoring lies in a high degree of standardisation (same age and origin, as well as known history and health status of the exposed fish at the beginning of the experiment) and controlled conditions. However, caging experiments are adversely affected by artificial feeding (biomagnification of contaminants does not occur), limited exposure times, unnaturally high densities (especially unfavourable for nonschooling fish species like brown trout) and caging stress. Caging is suboptimal for brown trout as far as the biological and ethological requirement of this species is concerned. It could be expected that the resulting caging stress induced strong disturbance of the hydromineral equilibrium and that for instance when working hard to maintain this equilibrium, the gills are more sensitive to chemicals in caged fish (active monitoring) than in wild fish (passive monitoring).

Aspects of the passive monitoring may also have contributed to the histopathological differences. Wild fish may avoid acute pollution peaks of sewage which at first runs in a plume downstream as it gradually mixes with the river water. Thus wild fish, when escaping the plume, can reduce both the concentration and length of their exposure, whereas caged fish are unable to avoid the water charged with pollutants. Passively monitored wild fish also (I) show higher interindividual variability (e.g. due to variable ages, genetic predisposition) than the more homogenous group of experimental fish used in the active monitoring; (II) are able to migrate. The location where they are caught is therefore not necessarily a site they have inhabited for a long period, thus they might have been exposed to a different water quality; (III) have a unknown history (feeding grounds, migrations, territories etc.). However the primary advantage of the passive monitoring is that the organisms investigated have had a long term exposure to the 'real' environment with all influencing factors including contamination, with all the different living-spaces available for the fish, natural fish densities and food-chain (biomagnification). We suppose, that the more pronounced liver and kidney indices diagnosed in wild fish compared with caged fish may firstly be due to biomagnification processes of contaminants in the food-chain of wild fish, and secondly to the longer exposure time. The positive correlation of the liver and kidney indices of the actively monitored fish with exposure time indicates that higher liver and kidney indices could be reached with longer exposure times, possibly approaching the degree of alterations observed in wild trout.

The liver showed the most distinctive alterations compared with the slight histological liver lesions in the reference trout. The liver index of waste water exposed WW-trout or trout caught downstream of the STW effluents was 268 and $426 \%$ of that from the reference group, respectively. This is in accordance with the results of Schmidt et al. (1999) who reported an increase of up to $228 \%$ in trout exposed to treated sewage for 8 months compared with reference trout held in tap water. Pericholangiar fibrosis with lymphohistiocytic infiltration was a prevalent lesion (wild fish: $>80 \%$; caged fish in the river: $>44 \%$ ). The effluents from the STW increased intensity and relative risk (prevalence ratio) for trout to acquire this lesion. This is in accordance with the results of Myers et al. (1994b), who found a higher relative risk value for pericholangiar fibrosis with increasing pollution. This lesion is not pathognomic for a specific substance, but is a common feature of irritation of the bile ducts by xenobiotics (Hinton \& Laurén, 1990). It has been diagnosed in fish exposed to treated sewage (e.g. Schmidt et al., 1999), to pulp and paper mill effluents (e.g. Adams et al., 1996; Teh et al., 1997) and in fish living in water contaminated with polychlorinated biphenyls (PCB), polycyclic aromatic hydrocarbons (PAH) and DDT (e.g. Myers et al., 1994a). Necrosis, structural changes of hepatocytes and activation of the RES were additional lesions that occurred more often in trout exposed to sewage than in trout of the other groups. Necrotic and inflammatory processes, also found in the present 
study, have been described in fish exposed to PCB, PAH and pesticide polluted water (Peters et al., 1987; Schwaiger et al., 1997), to pulp and paper mill effluents (Adams et al., 1996) and to treated sewage (Bucher \& Hofer, 1993). However, these alterations are also not specific for a certain substance (Meyers \& Hendricks, 1985).

In accordance with Couillard et al. (1988) and Brueggemann et al. (1995), who reported the gills to be the most sensitive organ to reveal histopathological effects of treated waste water, the most distinctive difference between the groups of the active monitoring was present in the gills. Alterations enhanced by discharged effluents from the STW were plasma alterations in epithelial cells, deformation of the lamellae, hyperplasia of the epithelium and fusion of lamellae. All these lesions are not pathognomic for a particular substance, but occur under a wide range of irritant-exposure conditions (Mallatt, 1985; Hinton \& Laurén, 1990). However, hyperplasia of the epithelial cells has been repeatedly associated with $\mathrm{NH}_{3}$ (e.g. Smith \& Piper, 1975; Carline et al., 1987; Lang et al., 1987; Narain et al., 1990) and $\mathrm{NO}_{2}$ (e.g. Michael et al., 1987). In our study, most measurements of these compounds revealed levels above the threshold values of the sewage effluents (see Table 2 and Escher et al., 1999). Monthly measurements during the study, performed approximately two kilometres downstream of the outlet, revealed $\mathrm{NH}_{3}$ values of $0.032-0.177 \mathrm{mg} \mathrm{l}^{-1}$. Such concentrations of $\mathrm{NH}_{3}$ are known to have deleterious effects on gill histology: Smith \& Piper (1975) reported severe hyperplasia of epithelial cells following a 6-12 months exposure of rainbow trout to $0.017 \mathrm{mg} \mathrm{l}^{-1} \mathrm{NH}_{3}$. Carline et al. (1987) found gill damage in brown trout exposed to 0.004-0.055 $\mathrm{mg} \mathrm{l}^{-1} \quad \mathrm{NH}_{3}$ during 12 months. According to Alabaster \& Lloyd (1982) a threshold value of $0.025 \mathrm{mg} \mathrm{l}^{-1} \mathrm{NH}_{3}$ for chronic exposure of fish is acceptable. $\mathrm{NO}_{2}$ levels in the river downstream of the STW ranged from 0.100 to $0.296 \mathrm{mg} \mathrm{l}^{-1}$. The toxicity of $\mathrm{NO}_{2}$ is highly dependent on the chloride concentration in the water. The acute toxicity of $\mathrm{NO}_{2}$ at a chloride concentration of $8-10 \mathrm{mg} \mathrm{Cl} \mathrm{Cl}^{-1}$, the average measured downstream the STW discharge, lies between 12.17 and $39.8 \mathrm{mg} \mathrm{l}^{-1}$. Thus the concentration measured in the river is far below the values known to have lethal effects on the fish
(Müller, 1990), and even remained lower than the concentrations which had no observable effect (NOEC) (for 8-10 $\mathrm{mg} \mathrm{Cl}^{-} \mathrm{l}^{-1}: 0.3-0.7 \mathrm{mg} \mathrm{l}^{-1}$ ).

In conclusion, the results of the present paper indicate an effect of the water quality on the histopathological status of the examined organs of brown trout. In both monitorings, trout exposed to river water supplemented with treated waste water of the STW Lyss showed higher histopathological indices than trout caught upstream of the discharge point of the STW or kept in river water only. This indicates that either irritants in the waste water effluents (e.g. toxicants, insoluble substances), or changed environmental conditions due to the effluents from the STW (e.g. temperature, dissolved oxygen, $\mathrm{pH}$ ) had a detrimental impact. However, even river water upstream of the STW induced liver alterations, and to a lesser extent gill and kidney lesions. This suggests that the river water itself is polluted, probably due to STW in the upper parts of the river system (see Bernet et al., 2001).

Although both monitoring approaches clearly revealed a deleterious effect of discharged effluents from the STW, data from the two monitoring approaches showed only partial comparability: In wild fish, the liver was the most affected organ and showed distinctive differences between the two groups. In caged fish, the gills were the most sensitive organ to reveal histopathological effects of treated waste water. Because of the difficulties to tease out detrimental effects of chemicals and substances on fish health and/or biology (due to multitude of environmental variables, inherent attributes of fish biology, huge variability in fish responses, etc.), it is necessary to take a 'weight of evidence approach' using several lines of evidence (Rolland, 2000), as for instance realised in using two approaches in the presented study. However, from a practical perspective, if only a single monitoring approach is possible, we would propose a passive monitoring if, (I) it is the aim to investigate the health status of a resident fish population, (II) the responses to the 'real' environmental contamination (including long-term exposure, biomagnification etc.) should be investigated, (III) the wild fish population is large enough to allow samplings of fish with enough specimens of comparable size and sex, (IV) the biomarkers to be measured are known to react sensitively to caging stress (e.g. sex- 
steroids, Munkittrick et al., 1998). In contrast, active monitorings are advantageous if, (I) biomarkers with high interindividual responses are to be investigated, because fish of same origin and age, or even genetically narrowly related can be exposed, (II) short-term responses will be investigated which can reveal effects of stressors within a short exposure period, (III) standardised conditions, and the elimination of confounding factors are important for the interpretation and evaluation of the data.

In this study, it was not possible to establish a causal link between histological lesions and a specific irritant. Among the chemicals detected in the river and in the effluents from the STW, unionised ammonia $\left(\mathrm{NH}_{3}\right)$, partly exceeding the threshold values, is a probable causes for the histopathological lesions.

\section{Acknowledgements}

We thank Dr M. Escher for his help with the experiments. Thanks go to the staff of the sewage treatment works Lyss for their care in fish keeping, for providing laboratory facilities during the samplings, and for data concerning waste water effluents parameters. We are grateful to the Laboratory of Histology of the Institute of Animal Pathology, University Berne, for preparing the histological slides. Thank goes to J. Ramseier and G. Zürcher for catching the wild fish. P. Girling is acknowledged for English corrections. This study was supported by grants from the WolfermannNägeli-Stiftung, Zurich, the Burgergemeinde of Berne, the Swiss Agency for Environment, Forests and Landscape (SAEFL), the Water and Soil Protection Laboratory of the District of Berne (GBL) and the Fisheries Authorities of Berne.

\section{References}

Adams, S. M., K. D. Ham, M. S. Greeley, R. F. LeHew, D. E. Hinton \& C. F. Saylor, 1996. Downstream gradients in bioindicator responses: point source contaminant effects on fish health. Canadian Journal of Fisheries and Aquatic Sciences 53: 2177-2187.

Alabaster, J. S. \& R. Lloyd, 1982. Water Quality Criteria for Freshwater Fish, Butterworth Scientific, London.

Aquaplus, 1993. Beurteilung der Gewässergüte und der Ökomorphologie in der Alten Aare und im Lyssbach. Vollzugskonzept Siedlungsentwässerung Kanton Bern. Amt für
Gewässerschutz und Abfallwirtschaft, Bau-, Verkehrs- und Energiedirektion des Kantons Bern, Bern.

Bernet, D., H. Schmidt, W. Meier, P. Burkhardt-Holm \& T. Wahli, 1999. Histopathology in fish: proposal for a protocol to assess aquatic pollution. Journal of Fish Diseases 22: 24-35.

Bernet, D., H. Schmidt, T. Wahli \& P. Burkhardt-Holm, 2001. Auswirkung von geklärtem Abwasser auf infektiöse Krankheiten bei der Bachforelle (Salmo trutta L.). Fischökologie 12: $1-16$.

Brueggemann, R., J. Schwaiger \& R. D. Negele, 1995. Applying hasse diagram technique for the evaluation of toxicological fish tests. Chemosphere 30: 1767-1780.

Bucher, F. \& R. Hofer, 1993. The effects of treated domestic sewage on three organs (gills, kidney, liver) of brown trout (Salmo trutta). Water Research 27: 255-261.

Burkhardt-Holm, P., M. Escher \& W. Meier, 1997. Waste-water management plant effluents cause cellular alterations in the skin of brown trout. Journal of Fish Biology 50: 744-758.

Burkhardt-Holm P., A. Peter \& H. Segner, 2002. Decline of fish catches in Switzerland. A balance between analysis and synthesis. Aquatic Science 64: 36-54.

Burrows, R. E., 1964. Effects of accumulated excretory products on hatchery-reared salmonids. Research Report. US Fish and Wildlife Service 66: 1-12.

Carline, R. F., A. J. Benson \& H. Rothenbacher, 1987. Long term effects of treated domestic wastewater on brown trout. Water Research 21: 1409-1415.

Couillard, C. M., R. A. Barman \& J. C. Panisset, 1988. Histopathology of rainbow trout exposed to a bleached kraft pulp mill effluent. Archives of Environmental Contamination and Toxicology 17: 319-323.

Escher, M., T. Wahli, S. Büttner, W. Meier \& P. BurkhardtHolm, 1999. The effect of sewage plant effluents on brown trout (Salmo trutta fario): a cage experiment. Aquatic Science 61: 93-110.

Frick, E., D. Nowak, C. Reust \& P. Burkhardt-Holm, 1998. Der Fischrückgang in den schweizerischen Fliessgewässern. Gas-Wasser-Abwasser 4: 261-264.

Friedl, C., 1999. Fischrückgang in schweizerischen Fliessgewässern. Swiss Federal Office of Environment, Forests and Landscape, Bern. Mitteilungen zur Fischerei 63: 1-32.

GSchV, 1998. Gewässerschutzverordnung. Berne, SR 814.201, Council of Ministers, Switzerland.

Hinton, D. E. \& D. J. Laurén, 1990. Integrative histopathological approaches to detecting effects of environmental stressors on fishes. American Fisheries Society Symposium 8: 51-66.

Huggett, R. J., R. A. Kimerle, P. M. Mehrle Jr. \& H. L. Bergman, 1992. Biomarkers. Lewis Publishers, Boca Raton.

Lang, T., G. Peters, R. Hoffmann \& E. Meyer, 1987. Experimental investigations on the toxicity of ammonia: effects on ventilation frequency, growth, epidermal mucous cells, and gill structure of rainbow trout Salmo gairdneri. Diseases of Aquatic Organisms 3: 159-165.

Lindesjöö, E. \& J. Thulin, 1990. Fin erosion of perch (Perca fluviatilis) and ruffle (Gymnocephalus cernua) in a pulp mill effluent. Diseases of Aquatic Organisms 8: 119-126.

Mallatt, J., 1985. Fish gill structural changes induced by toxicants and other irritants: a statistical review. Canadian Journal of Fisheries and Aquatic Sciences 42: 630-648. 
McCarthy, J. F. \& L. R. Shugart, 1990. Biomarkers of Environmental Contaminations. Lewis Publisher, Boca Raton.

Meyers, T. R. \& J. D. Hendricks, 1985. Histopathology. In Rand, G. M. \& S. R. Dentrocelli (eds), Fundamentals of Aquatic Toxicology. Hemisphere Publishing Co., New York: 283-331.

Michaelm M. I., A. M. Hilmy, N. A. El-Domiaty \& K. Wershana, 1987. Serum transaminases activity and histopathological changes in Clarias lazera chronically exposed to nitrite. Comparative Biochemistry and Physiology [C] 86: 255-262.

Mitz, S. V. \& J. P. Giesy, 1985. Sewage effluent biomonitoring I. Survival, growth, and histopathological effects in Channel Catfish. Ecotoxicology and Environmental Safety 10: 2239.

Müller, R., 1990. Stickstoff-Toxizität für Fische und herzuleitende Grenzwerte. Eawag-News 30: 33-36.

Munkittrick, K. R., M. E. McMaster, L. H. McCarthy, M. R. Servos \& G. J. Van Der Kraak, 1998. An overview of recent studies on the potential of pulp-mill effluents to alter reproductive parameters in fish. Journal of Toxicology and Environmental Health, Part B 1: 347-371.

Myers, M. S., C. M. Stehr, O. P. Olson, L. L. Johnson, B. B. McCain, S.-L. Chan \& U. Varanasi, 1994a. Relationships between toxicopathic hepatic lesions and exposure to chemical contaminations in English Sole (Pleuronectes vetulus), Starry Flounder (Platichthys stellatus), and White Croaker (Genyonemus lineatus) from selected marine sites on the Pacific Coast, USA. Environmental Health Perspectives 102: 200-215.

Myers, S. M., L. L. Johnson, O. P. Olson, C. M. Stehr, D. P. Lomax, B. H. Horness, B. F. Anulacion, M. L. Willis, T. K. Collier, B. B. McCain, J. E. Stein \& U. Varanasi, 1994b. Toxicopathic hepatic lesions and other biomarkers of exposure to chemical contaminants in marine bottomfish species from the northeast and pacific coast, USA. In Bylund, G. \& L.-G. Lönnström (eds), Diseases and Parasites of Flounder (Platichthys flesus) in the Baltic Sea. The Baltic Marine Biologists Publication, Turku/Abo: 81-98.

Narain A. S., A. K. Srivastava \& B. B. Singh, 1990. Gill lesions in the perch, Anabas testudineus, subjected to sewage toxicity. Bulletin of Environmental Contamination and Toxicology 45: 235-242.
Pedroli, J.-C., B. Zaugg \& A. Kirchhofer, 1991. Verbreitungsatlas der Fische und Rundmäuler der Schweiz. Schweizerisches Zentrum für die kartografische Erfassung der Fauna, Neuchâtel.

Peters, N., A. Köhler \& H. Kranz, 1987. Liver pathology in fishes from the lower Elbe as a consequence of pollution. Diseases of Aquatic Organisms 2: 87-97.

Rolland, R. M., 2000. Ecoepidemiology of the effects of pollution on reproduction and survival of early life stages in teleosts. Fish and Fisheries 1: 41-72.

Rüfenacht, H. U. \& M. Spörri, 1988. Chemisch-physikalische sowie fischereibiologische und makrofaunistische Untersuchungen an der Alten Aare. Diploma thesis, University of Berne.

Sachs, L., 1999. Angewandte Statistik, Springer-Verlag, Berlin.

Schmidt, H., D. Bernet, T. Wahli, W. Meier \& P. BurkhardtHolm, 1999. Active biomonitoring with brown trout and rainbow trout in diluted sewage plant effluents. Journal of Fish Biology 54: 585-596.

Schwaiger, J., R. Wanke, S. Adam, M. Pawert, W. Honnen \& R. Triebskorn, 1997. The use of histopathological indicators to evaluate contaminant-related stress in fish. Journal of Aquatic Ecosystem Stress and Recovery 6: 75-86.

Sindermann, C. J., 1979. Pollution-associated diseases and abnormalities of fish and shellfish: a review. Fish Bulletin 76: 717-749.

Smith, C. E. \& R. G. Piper, 1975. Lesions associated with chronic exposure to ammonia. In Ribelin, W. E. \& G. Migaki (eds), The Pathology of Fishes. University of Wisconsin Press, Madison: 497-514.

Snieszko, S. F., 1974. The effects of environmental stress on outbreaks of infectious diseases of fishes. Journal of Fish Biology 6: 197-208.

Teh, S. J., S. M. Adams \& D. E. Hinton, 1997. Histopathologic biomarkers in feral freshwater fish populations exposed to different types of contaminant stress. Aquatic Toxicology 37: 51-70.

Welch, E. B. \& T. Lindell, 1980. Fish. In Welch, E. B. \& T. Lindell (eds), Ecological Effects of Waste Water. Cambridge University Press, Cambridge: 262-298.

Wester, P. W. \& J. H. Canton, 1991. The usefulness of histopathology in aquatic toxicity studies. Comparative Biochemistry and Physiology [C] 100: 115-117. 